\title{
Detection of viable but non cultivable Escherichia coli after UV irradiation using a lytic $Q \beta$ phage
}

\author{
Myriam Ben Said • Otaki Masahiro • \\ Abdennaceur Hassen
}

Received: 9 October 2009 / Accepted: 28 December 2009/Published online: 6 February 2010

(C) The Author(s) 2010. This article is published with open access at Springerlink.com

\begin{abstract}
In order to qualify the germicidal efficacy of ultraviolet (UV) disinfection system, we generally determine the reduction of viable bacteria after UV-C irradiation. However, the simple count of viable and cultivable bacteria in usual media cannot reflect whether or not the UV dose applied to disinfect water is sufficient to inactivate bacteria. Indeed, there is a bacterial mix in the UV-treated water: dead bacteria, viable and cultivable bacteria and viable but noncultivable bacteria (VBNC). The third type of bacteria can constitute a potential risk for public health. In fact, VBNC bacteria can be active and cause diseases. Consequently, the combination of a conventional method used to measure colony-forming ability after UV disinfection and the determination of adsorption constants of a lytic $\mathrm{Q} \beta$ phage in relation to irradiated host cells by an increased UV dose (Escherichia coli ATCC 13965) allows the detection of active bacteria, which lose their cultivability in usual growth media, but keep the phage susceptibility.
\end{abstract}

Keywords UV-inactivation - VBNC bacteria - Lytic phage . Active bacteria

M. Ben Said $(\bowtie) \cdot$ A. Hassen

Water Treatment and Recycling Laboratory (LTRE),

Water Research and Technologies Centre (CERTE),

BP 273, 8020 Borj-Cedria,

Tunis, Tunisia

e-mail: myriam_rebia@yahoo.fr

O. Masahiro

Department of Human and Environment Sciences,

Ochanomizu University,

2-1-1 Otsuka, Bunkyo-Ku,

Tokyo 112-8610, Japan

\section{Introduction}

Ultraviolet-C (UV-C) radiation has been suggested as one of the successful disinfection practices for water treatment. Therefore, UV-sterilization has become a practical solution for safe disinfection of water. The effectiveness of UV light in biological inactivation arises primarily from the fact that DNA molecules absorb UV photons between 200 and $300 \mathrm{~nm}$, with peak absorption at $254 \mathrm{~nm}$ (Jeffrey et al. 1990). This absorption creates damage in the DNA by altering the nucleotide base pairing, thereby creating new linkages between adjacent nucleotides on the same DNA strand. This damage occurs particularly between pyrimidine bases. Two types of mutagenic lesions in DNA were determined: cyclobutane pyrimidine dimers (CPD) formed between the C-4 and C-5 positions of adjacent thymidine or cytosine residues, and pyrimidine (6-4) pyrimidone (6-4) photoproducts formed between the $\mathrm{C} 6$ and $\mathrm{C} 4$ position of adjacent pyrimidine residues, most often between $\mathrm{T}-\mathrm{C}$ and C-C residues (Zimmer and Slawson 2002). If the damage goes unrepaired, the accumulation of DNA photoproducts can be lethal to cells through the blockage of DNA replication and RNA transcription, which ultimately result in reproductive cell death. However, UV disinfection is known to have some problems, one of them being reactivation. Biological systems have evolved mechanisms to appropriately respond to environmental stresses that can damage proteins and DNA (Arrieta et al. 2000). In this case, to respond to nonlethal or moderate germicidal dose, bacteria generally possess molecular mechanisms to restore DNA lesions (Lindauer and Darby 1994).

Most bacteria repair these lesions in two ways: lightdependent photoreactivation catalyzed by an enzyme name photolyase, and light-independent restore mechanisms such as nucleotide excision repair (Liltved and Landfald 1996). The 
goal is the production of safe water; thus, after disinfection of water, health protection programs require to estimate the level of contamination of treated water (Jeffrey et al. 1990).

The enumeration of various indicator bacteria is usually used to evaluate the fecal contamination of water and the sanitary risk associated with various water utilizations (bathing water, production of drinking water, etc.) (Armisen and Servais 2004). Among a variety of indicator bacteria, Escherichia coli, a type of fecal coliform bacteria, is commonly found in the intestines of animals and humans (Pommepuy et al. 1996). The abundance of E. coli was shown to be more related to the presence of pathogenic bacteria. Thus, accurate enumeration of $E$. coli is important to assess microbiological water quality (Armisen and Servais 2004; Sharifi-Yazdi and Darghahi 2006). Classical methods for enumerating $E$. coli are based on culture in liquid (most probable number, MPN) or solid (plate count) media (Byrd and Colwell 1991). Nevertheless, it is well known that the bacteria and especially the fecal ones lose their cultivability in culture media while preserving their viability (Chedad and Assobhei 2007). It should be noted that viable but nonculturable (VBNC) bacteria in the treated water could maintain their virulence; consequently, the simple estimation of viable bacteria, before and after water treatment, is not enough to limit the sanitary risk related to maintained virulence (Colwell et al. 1996; Besnard et al. 2002).

The aim of the present study was to determine the relationship between bacteria (E. coli ATCC 13965) and lytic bacteriophage $(\mathrm{Q} \beta$ phage), in order to detect the presence of active UV-irradiated bacteria undetected in usual culture media.

\section{Materials and methods}

Bacterial strain and bacteriophage

The RNA F-specific coliphage $\mathrm{Q} \beta$ phage and its host, E. coli, were obtained from the American Type Culture Collection (23631-B1 and 13965, respectively). Q $\beta$ phage has been commonly recommended for modeling viral behavior in water (Espinosa et al. 2009) and has also been used in biological actinometry (Biodosimetry) (Fallon et al. 2007). This bio-assay was based on the dose-response relationship of an indicator microorganism to back-calculate UV dose based on inactivation data.

In this study, we used $\mathrm{Q} \beta$ phage as an indicator of active VBNC bacteria after UV irradiation.

Continuous UV-C irradiation

A continuous low pressure (LP) system containing monochromatic output lamp at $254 \mathrm{~nm}$ was used. The irradiance of the LP lamp was measured using potassium iodide/iodate actinometry $\left(\mathrm{KI} / \mathrm{KIO}_{3}\right)$ according to Rahn et al. (2003).

Using KI actinometry, the molar absorption coefficient was $\varepsilon=27.7 \mathrm{M}^{-1} \mathrm{~cm}^{-1}$ in a $0.6 \mathrm{M} \mathrm{KI} / 0.1 \mathrm{M} \mathrm{KIO}_{3}$ solution, quantum yield at $254 \mathrm{~nm}$ was 0.72 for the LP lamp, sample volume $20 \mathrm{ml}$, and the area of the Petri dish used for irradiation was $19.6 \mathrm{~cm}^{2}$. The experience was performed in triplicate. The UV dose measured by chemical actinometry was equal to $0.5 \mathrm{~mJ} / \mathrm{cm}^{2}$.

\section{UV-irradiated bacteria}

For dose/survival and reactivation experiments, the strain of E. coli was cultured in Luria-Bertani broth (LB). Bacterial suspension was diluted in saline Phosphate Buffer (PBS) in order to obtain a concentration ranged from $1 \times 10^{5}$ to $1 \times$ $10^{6}$ bacteria per $\mathrm{ml}$, and the resulting preparations were used for irradiation experiments. A volume of $20 \mathrm{ml}$ of the suspended culture was transferred into a standard Petri dish for exposure to the continuous UV-light treatment. The samples were exposed to the UV-light for chosen increasing UV dose $\left(0,45,60,90\right.$, and $\left.120 \mathrm{~mJ} / \mathrm{cm}^{2}\right)$. Following exposure, treated and control samples were enumerated on LB agar plates.

Viable cell counts

Viable cell counts were taken before and immediately after UV exposure. A $100-\mu 1$ portion of each cell suspension was removed in order to prepare serial dilutions in PBS buffer. Portions $(100 \mu \mathrm{l})$ of the appropriate serial dilutions were spread in duplicate onto LB agar before scoring for survivors. The number of colony-forming units $(\mathrm{CFU} / \mathrm{ml})$ were determined after $24 \mathrm{~h}$ of incubation at $37^{\circ} \mathrm{C}$. The fraction of viable and cultivable bacteria was calculated by dividing the number of CFU in the UV-treated sample $(N)$ by the number of $\mathrm{CFU}$ in the unirradiated sample at time zero $\left(N_{0}\right)$.

\section{$\mathrm{Q} \beta$ phage replication experiments}

To investigate the presence of active bacteria in the UV-irradiated sample, $\mathrm{Q} \beta$ phage adsorption experiments were performed with a modification of the procedure of Woody and Cliver (1995). UV-irradiated suspensions of host cells were infected with $\mathrm{Q} \beta$ phage. After infection, and at the indicated time intervals (every $5 \mathrm{~min}$ after infection), $0.1 \mathrm{ml}$ was removed from different suspensions, and after a cumulative dilution, $0.1 \mathrm{ml}$ samples of each dilution of samples was periodically assayed to determine the kinetic of phage adsorption to the host cell. The phage titration was determined using the double-layer agar plate method. 
$\mathrm{Q} \beta$ phage replication experiments were determined at time zero, before UV irradiation, using initial cell and phage densities to know the optimal timing of phage adsorption.

In this work, we repeated all experiments more than 3 times, and we have chosen to work with average values. This choice was based on the use of different mathematical models to simulate the $\mathrm{Q} \beta$ phage's replication and to determine the phage growth's kinetic parameters.

\section{Simulating $\mathrm{Q} \beta$ phage's growth}

Our purpose in employing simulations is to obtain predictions of phage population growth rates and to determine the impact of irradiation condition of host bacteria on phage population growth rates.

Our approach to modeling phage adsorption is equivalent to the model employed by Levin et al. (1977) and reported by Abedon et al. (2001). The modeling of $\mathrm{Q} \beta$ phage adsorption was applied to investigate the impact of host cell irradiation condition in the phage adsorption rates. The adsorption constant $(k)$, and the density of uninfected host cells $\left(N^{\prime}\right)$ were determined and compared to a control test determined at time zero using initial cell and phage densities. In addition, the adsorption time $\left(t_{\mathrm{A}}\right)$ was determined according to Wang et al. (1996).

Using the mathematical models adopted by Wang et al. (1996) and Abedon et al. (2001), we can quantify the adsorption rates of $\mathrm{Q} \beta$ phage in relationship to the different UV treatment dose of host cell. Consequently, the comparison and the analysis of different adsorption kinetics constants determined after infection of irradiated host cells by $\mathrm{Q} \beta$ phage allow the detection of active bacteria that lose the viability and cultivability in usual media.

\section{Titration of $\mathrm{Q} \beta$ phage}

Irradiated cell-phage suspensions were incubated at $37^{\circ} \mathrm{C}$. After $18 \mathrm{~h}$, the cell-phage mixtures were filter sterilized using a $0.45-\mu \mathrm{m}$ syringe filter to obtain free phage in the filtrate, and the supernatants were diluted in order to determine the titration of phage. The phage titer was determined by using a standard double-layer agar plate. After appropriate dilution with PBS buffer, $0.1 \mathrm{ml}$ of phage sample and $0.1 \mathrm{ml}$ of actively growing culture of $E$. coli $\left(10^{6} \mathrm{CFU} / \mathrm{ml}\right)$ were added to $3 \mathrm{ml}$ of soft agar (maintained at $48^{\circ} \mathrm{C}$ ). The mixture was overlaid on TSA agar plates and incubated for $18 \mathrm{~h}$ at $37^{\circ} \mathrm{C}$ to enumerate plaques. The phage titration experiment was determined at time zero using initial unirradiated cells and phage densities. All phage adsorption experiments were done more than three times, to verify the sensibility and the reproducibility of this method.

\section{Results and discussion}

The inactivation kinetic of Escherichia coli: UV Dose-Response

The intrinsic kinetics of bacterial inactivation as a result of exposure to UV radiation are a function of UV-C dose, expressed as the product of germicidal radiation intensity $(I)$ and exposure time $(t)$.

Several mathematical relationships have been developed to describe bacterial responses to UV irradiation. UV dose plays an important role in all bacterial inactivation models for UV irradiation (Qualls et al. 1997). An inactivation graph was constructed by plotting the logarithm of the fraction of surviving bacteria versus UV dose (Fig. 1.).

To determine the graph parameters, the model of ChickWatson was used:

$N / N_{0}=A \exp \left(-k I^{n} t\right)$

where $N_{0}$ is the number of viable cultivable bacteria before exposure to UV light, $N$ is the number of viable cultivable bacteria after exposure to UV light at time $t, A$ is the event corresponding to microorganism retaining viability following UV irradiation, $k$ is the coefficient of lethality, $I$ is the the UV-C intensity expressed in $\mathrm{mW} / \mathrm{cm}^{2}, t$ is exposure time (s), $n$ is the threshold level of series-event model, and $n=1$ for the first order Chick-Watson model. The constants $k$ and $A$ were determined by linear regression.

The inactivation kinetic (dose/response) according to the Chick-Watson model shows that a UV dose equal to $45 \mathrm{~mJ} / \mathrm{cm}^{2}$ corresponds to approximately $4 \mathrm{U}-\log _{10}$ units of inactivation, or $99.99 \%$ of inactivation of colony-forming ability. This value is equal of the UV dose usually used in Europe and the USA for the disinfection of drinking water. According to the literature, $40 \mathrm{~mJ} / \mathrm{cm}^{2}$ is sufficient

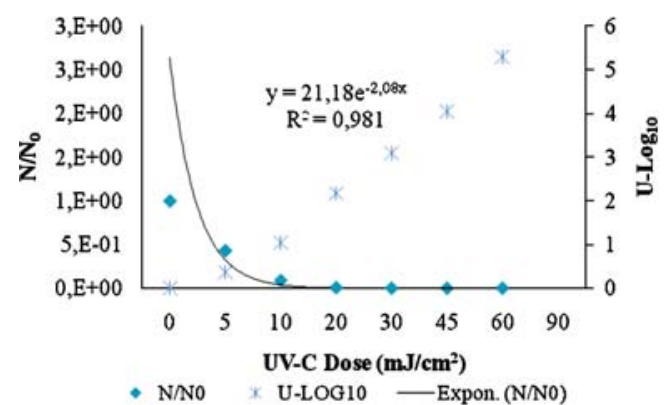

Fig. 1 Kinetics of Escherichia coli ATCC 13965 inactivation following exposure to UV-C irradiation according to Chick-Watson model. $y$ axis: reduction $=N / N_{0}$ where $N$ is the number of viable and cultivable cell after exposure to UV-C irradiation and $N_{0}$ is the number of viable and cultivable cell before exposure to UV light; $x$ axis $=I^{n} t$ where $I$ is UV intensity $\left(\mathrm{mW} / \mathrm{cm}^{2}\right), t$ is exposition time $(\mathrm{s}), n$ is threshold level of series-event model, and $n=1$ for the first order Chick-Watson model where error bars are not shown; differences between duplicates were not detected 
Fig. $2 \mathrm{Q} \beta$ phage adsorption kinetics dependence on host UV irradiation state (UV irradiation by $0,45,60,90$, and $120 \mathrm{~mJ} / \mathrm{cm}^{2}$ ). $P(t)=$ the free-phage concentration at time $(t), P_{0}=$ the initiated free-phage concentration at time zero $\left(t_{0}\right)$

to inactivate $4 \mathrm{U}-\log _{10}$ of pathogenic bacteria such as Legionella, enteric viruses, Cryptosporidium oocysts, and Giardia cysts (US-EPA 2003).

Exploitation of VBNC bacteria after UV irradiation

According to the result from the inactivation kinetic, E. coli lose the colony-forming ability after exposure to $45 \mathrm{~mJ} / \mathrm{cm}^{2}$ of UV light (nondetected CFU/ml; ND). Thus, we can conclude that UV irradiation was effective in reducing the number of indicator bacteria. But it is known that the loss of bacterial cultivability is not synonymous with death of bacteria. The question is: how can we test the presence of active but noncultivable bacteria in irradiated samples?

Detection of active Escherichia coli ATCC 13965 after UV-C irradiation: study of $\mathrm{Q} \beta$ phage adsorption in presence of VBNC host cell

The aim of this study was to examine the potential replication of the phage infecting $E$. coli irradiated by increasing UV doses. Each UV dose allows a growth state of host bacteria in culture media.

Based on UV-inactivation's kinetic curve of E. coli, the exposition of bacteria to UV dose equal to $45 \mathrm{~mJ} / \mathrm{cm}^{2}$ can allow the inactivation of $99.99 \%$ of bacteria. However, the irradiation of host bacteria by a UV doses equal to 60 and $90 \mathrm{~mJ} / \mathrm{cm}^{2}$ can allow the loss of cultivability of $E$. coli and the entry in the viable but noncultivable (VBNC) state with and without subsequent reactivation, respectively. Finally, the exposure of host bacteria by a higher UV dose $\left(120 \mathrm{~mJ} / \mathrm{cm}^{2}\right)$, a sub-lethal UV irradiation, can indicate the ability of lytic phage to detect active bacteria persisting in the irradiated suspension.

Series of experiments were conducted to determine, in part, the detection of active bacteria present in the irradiated suspension, and on the another hand, to reveal the capability of VBNC bacteria to support phage replication. Furthermore, we examined how the phage replication was influenced by the physiological state of bacterial host cells.

Study of $\mathrm{Q} \beta$ phage adsorption to the host cells: irradiated and unirradiated host cells

Data presented in Fig. 2 indicate the presence of bacteria in good phage susceptibility conditions. We can note that there are no inhibitory effects on the first step of phage replication (the adsorption phase), despite the irradiation of host cells by an increased UV-C dose.
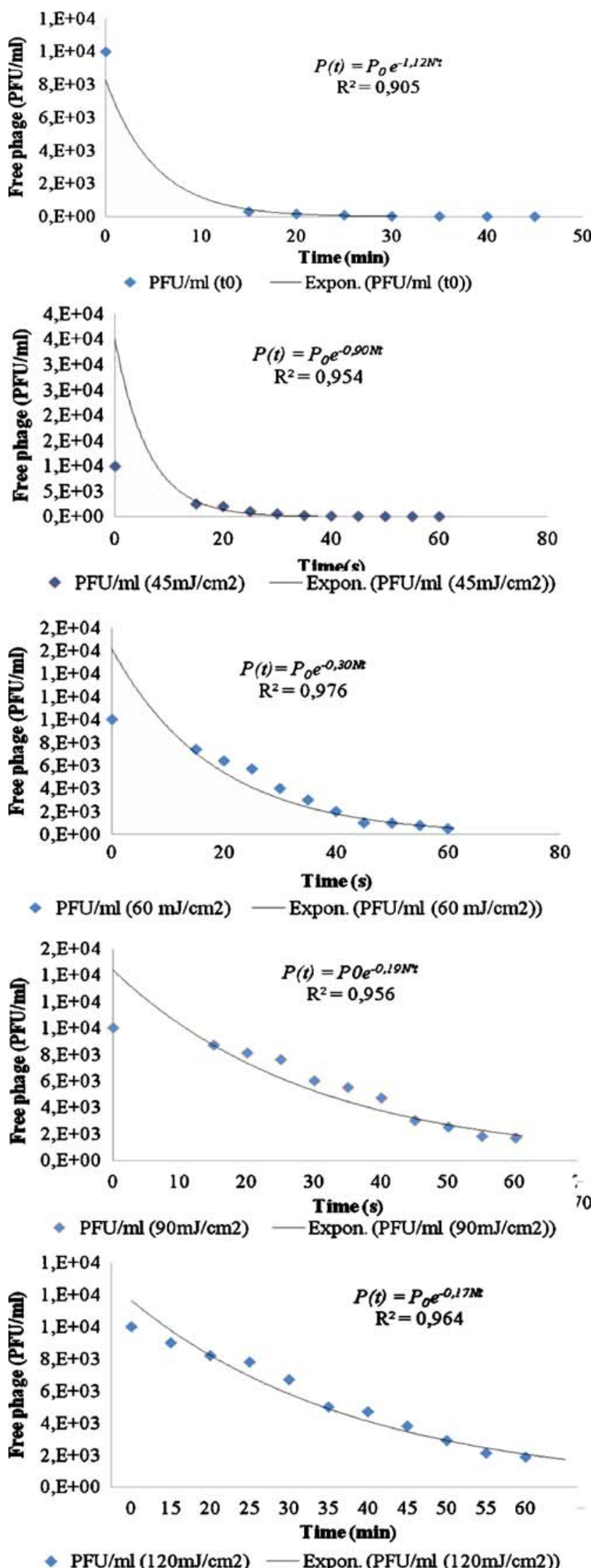
The modelling of phage adsorption was determined according to the model employed by Levin et al. (1977):

$P(t)=P_{0} e^{-k^{\prime} \cdot N^{\prime} \cdot t}=P_{0}\left(1-k^{\prime} \cdot N^{\prime} \cdot t\right)$

where $P_{0}$ is the initiated free-phage concentration at $t_{0}$, $P(t)$ is the free-phage concentration at time $t, k^{\prime}$ is the phage adsorption constant, and $N^{\prime}$ is the density of uninfected host cells.

The adsorption constant $k^{\prime}$, determined via analysis of the adsorption curves (Fig. 2), showed that the level of phage adsorption to host cells decrease with the increase of UV dose (Table 1). The changes in the phage growth parameters (decline of adsorption phage, elongation of latent period) were probably due to the changes of host quality (Woody and Cliver 1996).

For example, after inactivation of $99.99 \%$ of host bacteria, the $\mathrm{Q} \beta$ phage replication's kinetic parameters, are not affected. Although the phage adsorption rate, determined after exposure of host cell to UV dose equal to $120 \mathrm{~mJ} / \mathrm{cm}^{2}$, is lower than 6.5-fold compared to the adsorption constant determined at time zero before UV irradiation. In this case, the decrease of phage adsorption rate can be explained by the fact that the exposure of host bacteria to a sublethal dose can contribute to the disintegration or modification of bacteria cell caused by the bactericidal effect of UV light (Makarova et al. 2000).

Furthermore, it is well known that the phage adsorption rates are proportional to host cell surface area (Woody and Cliver 1996); thereby, bacteria can change the morphological shape as a strategy of bio-protection against stress and for survival in a hostile environment (Langer and HenggeAronis 1991). In our case, to escape or to minimize the germicidal effect of UV irradiation, bacteria have consequently changed their shape ; this change can have an effect on the phage adsorption by stopping or prolonging the timing of phage adsorption to the host cell.

\section{Determination of uninfected bacteria}

After fixing the timing of optimal phage adsorption at 45 min based on the interaction of initial cell and phage

Table 1 Determination of different parameters related to $\mathrm{Q} \beta$ phage growth kinetic

\begin{tabular}{|c|c|c|c|c|c|}
\hline \multirow[t]{2}{*}{ Parameter $^{\mathrm{a}}$} & \multicolumn{5}{|c|}{$\mathrm{UV}$ dose $\left(\mathrm{mJ} / \mathrm{cm}^{2}\right)$} \\
\hline & 0 & 45 & 60 & 90 & 120 \\
\hline$K^{\prime}$ & 1.12 & 0.9 & 0.3 & 0.19 & 0.17 \\
\hline$N^{\prime}$ & 0.019 & 0.024 & 0.066 & 0.0818 & 0.08 \\
\hline$t_{A}$ & 0.06 & 0.07 & 0.22 & 0.35 & 0.92 \\
\hline
\end{tabular}

${ }^{\text {a }} K^{\prime}$ Phage adsorption constant $(\mathrm{ml} / \mathrm{min}), N^{\prime}$ number of uninfected cells at time $15 \mathrm{~min}(\mathrm{cell} / \mathrm{ml}), t_{A}$ adsorption time ( $\mathrm{min} /$ host cell) densities (at time zero before UV radiation), it was possible to achieve reasonable simulation of the number of uninfected host cells after each was irradiated by increased UV dose samples according to the model of Levin et al. (1977).

The presumed density of uninfected cells can directly reflect the number of UV-inactivated bacteria compared with time zero before UV irradiation (maximum level of phage infectivity). The results had shown that the uninfected cells $\left(N^{\prime}\right)$ increase in alliance with the irradiation condition of host bacteria (Table 1). In fact, when we increase the UV exposure dose, the density of uninfected bacteria increases. The decrease of phage infectivity is related to the engagement of bacteria in different strategies of survival and mechanisms of repair (photo-reactivation and or dark repair).

According to Wang et al. (1996), in these explicit calculations, we define the time adsorption $\left(t_{\mathrm{A}}\right)$ as the mean free time (MFT), $t_{\mathrm{A}}=\left(k^{\prime} N^{\prime}\right)^{-1}$. The MFT represents the average length of time a cohort of free phages requires to adsorb to host cells expressed by $\mathrm{min} /$ host cell. Note that we have chosen the time $15 \mathrm{~min}$ to determine the initial uninfected host cells density, and we fixed this host cells density as an initial density of viable but noncultivable bacteria (VBNC) infected by a constant amount of phage ("Titration of $\mathrm{Q} \beta$ phage").

The results in Table 1 show a difference in the timing required for the $\mathrm{Q} \beta$ phage to be attached in the host cell. The extension of adsorption time $\left(t_{A}\right)$ is directly related to the quality of host cells. This result supports previous observations related to the decrease of adsorption kinetic constant $\left(k^{\prime}\right)$ and the increase of uninfected hosts cells. In fact, the fluctuations of phage growth parameters were directly caused by the change in host quality and, therefore, by the pressure of selection of good quality of host cells by the phage (Wang et al. 1996; Abedon et al. 2003).

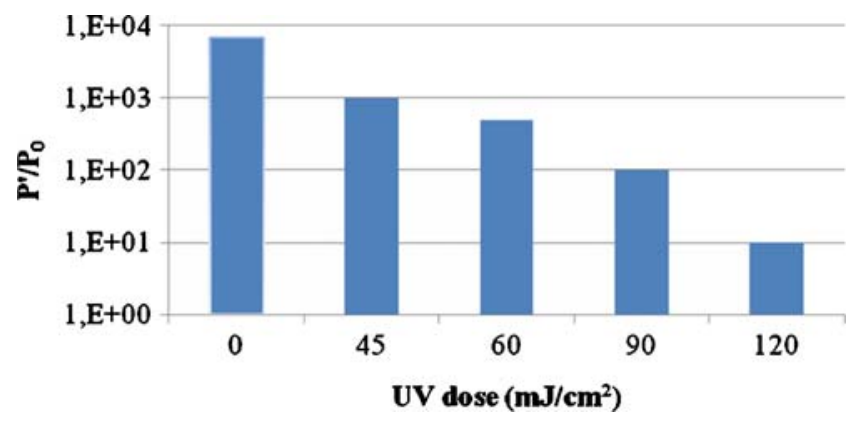

Fig. $3 \mathrm{Q} \beta$ phage titers dependence on host UV irradiation state after $18 \mathrm{~h}$ of incubation at $37^{\circ} \mathrm{C} . P_{0}$ is the initiated free-phage concentration at time zero $\left(t_{0}\right), P^{\prime}$ is the $\mathrm{Q} \beta$ phage titers after $18 \mathrm{~h}$ of incubation at $37^{\circ} \mathrm{C}$ in the presence of irradiated Escherichia coli by increased UV dose $\left(0,45,60,90\right.$, and $\left.120 \mathrm{~mJ} / \mathrm{cm}^{2}\right)$ 
Under UV exposure conditions, stressed bacteria has been converted in the viable but noncultivable state as a strategy of protection against the germicide effect of ultraviolet light (to economize on energy, induction of repair mechanisms, inhibit the generation of mutant bacteria, etc.).

The titration of $\mathrm{Q} \beta$ phage took place after $18 \mathrm{~h}$ of incubation at $37^{\circ} \mathrm{C}$ in the presence of susceptible host cells after irradiation by increasing UV dose. The titer of bacteriophage-infected host cells after UV irradiation by a dose equal to $45,60,90$, and $120 \mathrm{~mJ} / \mathrm{cm}^{2}$ is compared to the control suspension (Fig. 3).

The infection of different irradiated suspensions by $Q \beta$ phage allowed the detection of the presence or absence of active bacteria. In fact, despite the loss of the bacteria's cultivability in usual growth media after UV irradiation, and the change of the phage replication cycle (extension of latent period, decrease in the adsorption constant, etc.), a fraction of VBNC bacteria can allow a replication of phage with an enhancement in the phage titers after $18 \mathrm{~h}$ of incubation at $37^{\circ} \mathrm{C}$.

Compared to the control test (unirradiated host cell and the initial amount of $\mathrm{Q} \beta$ phage), we noted different levels of progeny phage release in relation to bacterial UV-C irradiation conditions (Fig. 3). The amount of phages released by irradiated host cells by $45 \mathrm{~mJ} / \mathrm{cm}^{2} \mathrm{UV}$ dose is higher than the amount of phages released by E. coli irradiated by 60,90 , and $120 \mathrm{~mJ} / \mathrm{cm}^{2} \mathrm{UV}$ doses. The decrease in the level of phage infectivity and release of maturated $\mathrm{Q} \beta$ progeny phage is directly related to the decrease of active bacteria's density caused by the bactericidal effect of UV irradiation.

We can conclude that a fraction of VBNC bacteria was able to allow the replication cycle of $\mathrm{Q} \beta$ phage despite their loss of cultivability in usual media. We can classify this part of the bacteria in the category of active but noncultivable (ABNC) bacteria.

\section{Conclusion}

We can conclude that phage growth kinetic parameters defining phage-host cell relationships accommodates changes in host cell quality (damaged cells by UV light, hostmorphological change, accumulation of photoproduct, etc).

Based on the phage replication proprieties, the obligatory intracellular phage replication, we can use phage as a biological materiel, easy to detect and to manipulate, for the estimation of water quality after disinfection and the detection of active indicator bacteria such as $E$. coli noncultivable in usual media.

The perspective of this study is to select polyspecific phages of a large bacterial infectivity spectrum, especially for pathogenic bacteria, and to standardize the technique developed in this study to control the bacteriological quality of water to guarantee the production of safe water.

Acknowledgments We are grateful to Professor Mourad Bédir, the General Director of Water Research and Technologies Centre (CERTE) for the confidence he placed in me during the whole period of my research, and his unconditional support. A special thanks to Shinobu Kazama-san, for her invaluable help during my training in Japan.

Open Access This article is distributed under the terms of the Creative Commons Attribution Noncommercial License which permits any noncommercial use, distribution, and reproduction in any medium, provided the original author(s) and source are credited.

\section{References}

Abedon ST, Herschler TD, Stopar D (2001) Bacteriophage latent-period evolution as a response to resource availability. Appl Environ Microbiol 9:4233-4241

Abedon ST, Hershler TD, Stopar D (2003) Experimental examination of bacteriophage latent-period evolution as a response to bacterial availability. Appl Environ Microbiol 69:7499-7506

Armisen TG, Servais P (2004) Enumeration of viable E. coli in rivers and wastewaters by fluorescent in situ hybridization. J Microbiol Meth 58:269-279

Arrieta JMA, Weinbauer MG, Herndl GJ (2000) Interspecific variability in sensitivity to UV radiation and subsequent recovery in selected isolates of marine bacteria. Appl Environ Microbiol 66:1468-1473

Besnard V, Federighi M, Declerq E, Jugiau F (2002) Environmental and physico-chemical factors induce VBNC state in Listeria monocytogenes. Vet Res 33:359-370

Byrd JXu, Colwell RR (1991) Viable but not culturable bacteria in drinking water. Appl Environ Microbiol 57:875-878

Chedad K, Assobhei O (2007) Etude de la survie des bactéries de contamination fécale (coliformes fécaux) dans les eaux de la zone ostréicole de la lagune de Oualidia (Maroc). Bull Inst Sci Rabat, Sciences de la Vie 29:71-79

Colwell RR, Brayton P, Herrington D, Tall B, Huq A, Levine MM (1996) Viable but nonculturable Vibrio cholerae 01 revert to a cultivable state in the human intestine, World J. Microbiol Biotechnol 12:28-31

Espinosa AC, Arias CF, Sánchez-Colón S, Mazari-Hiriart M (2009) Comparative study of enteric viruses, coliphages and indicator bacteria for evaluating water quality in a tropical high-altitude system. Environ Health 8:49

Fallon KS, Hargy TM, Mackey ED, Wright HB, Clancy JL (2007) Development and characterization of nonpathogenic surrogates for UV reactor validation. J AWWA 99:73-82

Jeffrey JB, Huai-Shu Xu, Colwell RR (1990) Viable but nonculturable bacteria in drinking water. Appl Environ Microbiol $57: 875-878$

Langer R, Hengge-Aronis R (1991) Growth phase-regulated expression of bolA and morphology of stationary-phase Escherichia coli cells are controlled by the novel sigma factor $\delta^{\mathrm{s}}$. Appl Environ Microbiol 173:4474-4481

Levin BR, Stewart FM, Chao L (1977) Resource limited growth, competition, and predation: a model and experimental studies with bacteria and bacteriophage. Am Nat 111:3-24

Liltved H, Landfald B (1996) Influence of liquid holding recovery and photoreactivation of survival of ultraviolet-irradiated fish pathogenic bacteria. Water Res 30:1109-1114 
Lindauer KG, Darby J (1994) Ultraviolet disinfection of waste water: effect of dose on subsequent photoreactivation. Water Res $28: 805-817$

Makarova KS, Aravind L, Wolf IY, Daly MJ (2000) Genome of the extremely radiation-resistant bacterium Deinococcus radiodurans viewed from the perspective of comparative genomics. Microbiol Mol Biol Rev 65:44-79

Pommepuy M, Butin M, Derrien A, Gourmelon M, Colwell RR, Cormier M (1996) Retention of enteropathogenicity by viable but nonculturable Escherichia coli exposed to seawater and sunlight. Appl Environ Microbiol 62:4621-4626

Qualls RG, Dorfman MH, Johnson D (1997) Evaluation of the efficiency of ultraviolet disinfection systems. Water Res 3:317-325

Rahn RO, Stefan MI, Bolton JR, Goren E, Shaw P-S, Lykke KR (2003) Quantum yield of the iodide-iodate chemical actinometer: dependence on wavelength and concentration. Photochem Photobiol 78:146-152
Sharifi-Yazdi MK, Darghahi H (2006) Inactivation of pathogenic bacteria using pulsed UV-light and its application in water disinfection and quality control. Acta Medica Iranica 44:305-308

US-EPA (2003) UV disinfection guidance manual. EPA, 815-D-03-007

Wang IN, Dykhuizen DE, Slobodkin LB (1996) The evolution of phage lysis timing. Evol Ecol 10:545-558

Woody MA, Cliver DO (1995) Effects of temperature and host cell growth phase on replication of f-specific RNA coliphage $\mathrm{Q} \beta$. Appl Environ Microbiol 61:1520-1526

Woody MA, Cliver DO (1996) Replication of coliphage Q $\beta$ as affected by host cell number, nutrition, competition from insusceptible cells and non-FRNA coliphages. Appl Environ Microbiol 82:431-440

Zimmer JL, Slawson RM (2002) Potential repair of Escherichia coli DNA following exposure to UV radiation from both medium- and low-pressure UV sources used in drinking water treatment. Appl Environ Microbiol 68:3293-3299 